\title{
THE EUROPEANIZATION OF BIOETHICS: OPPORTUNITIES FOR INTEGRATIVE ETHICAL REFLECTION ON THE BASIS OF INTRA-CULTURAL DIFFERENCES IN EUROPE ${ }^{1}$
}

UDC 608(4-672EU)

\author{
Ante Čović \\ Faculty of Humanities and Social Sciences, University of Zagreb, Croatia
}

\begin{abstract}
The article represents a reconstruction of theoretical framework in which the concept of integrative bioethics has been developed, as well as a verification of the idea of Europeanization of bioethics which has been sketched and postulated at the beginning of the comprehensive international project of establishing and instituializing the bioethical cooperation, mainly in the region of Southeast Europe. This idea found its firm foothold in the concept of integrative bioethics and in the discovery of the work of Fritz Jahr, which contributed to establishing the concept of European bioethics. Compositionally seen, this article is the result of synthesis of programmatic ideas presented in the initial phase of the above mentioned bioethical project, and ideas which represent the final point of it.
\end{abstract}

Key words: bioethics, new medical ethics, global bioethics, integrative bioethics, European bioethics, Fritz Jahr

The main and most important reason of the birth of bioethics should be looked for in the fact that the contemporary science has lost its orientation authority and existential competence for a contemporary human. Therefore, bioethics should be primarily understood as intellectual and existential field which creates orientation within this, in principle, new situation which is highly determined by factors of scientific and technological development. The orientation can still be reached in differently set situations, different means (methods) and different levels of elaboration. So far, bioethics has provided orientation in a ,new medical situation“ by means of direct moral reflections (called principlism), and then in the more broadly set situation of globalized subject field by the means of ethical reflection within the interdisciplinary frame. In

Received May $17^{\text {th }}, 2017 /$ Accepted May $22^{\text {th }}, 2017$

Corresponding author: Ante Čović

Faculty of Humanities and Social Sciences, University of Zagreb, Ivana Lučića 3, HR-10000 Zagreb, Croatia

E-mail: ante.covic1@zg.t-com.hr

${ }^{1}$ This article was previously published in: Muzur, A., Sass, H.-M. (eds.). Fritz Jahr and the Foundations of Global Bioethics: The Future of Integrative Bioethics, LIT Verlag, Münster et al., 2012, pp. 194-196. 
accordance with this, it is possible to differentiate two phases of the development of bioethics: the phase of moral and the phase of ethical reflection.

But since moral and ethical reflections, although necessary moments in establishing all forms of orientation, have proved to be insufficient methods for achieving orientation in the circumstances of threatening completion of scientific and technical civilization and the situation at the turn of the world historical epochs, the bioethics - following it orientation role, has become more aimed at the philosophical historical reflection. With this, it enters its new phase of development which will enable it to show all its orientation potentials. However, it implies the activation of not only history of philosophy but also the total Eurocontinental philosophical tradition in the methodology pattern of bioethics. This clearly shows that the Europeanization of bioethics is not an internal nor institutionalized problem of European bioethics, but a constitutional and developmental imperative of bioethics as such. This raises the question: why should the extensive task of Europeanization of bioethics and establishing the European bioethical horizon be carried out by those who live or those who gather at bioethical conferences on the geographic periphery of Europe. The answer is simple: because the horizon is the most open on the periphery.

The historical development of bioethics towards the stage of integrativity proceeded on the methodological plan as a gradual expansion of the circle of perspectives on addressing bioethical problems, from accepting ethical plurality to scientific interdisciplinarity and pluriperspectivity. On the other hand, the processes of both expanding and deepening of problem areas in bioethics were taking place in parallel, ranging from healthcare problems and biomedical research to issues of non-human living beings and general conditions of life sustainment (ecology), and exploring the profound philosophico-historical dimension of these problems.

The history of bioethics can be divided into three development stages in which major breakthroughs were achieved in the methodological constituting of bioethics and in determining its scope of research. Development changes were competently confirmed in the phase definitions of bioethics, which can be found in the first and the second edition of the Encyclopedia of Bioethics and in newer texts that emerged within the project of "integrative bioethics". The precise period delimitations of these development stages are rendered more difficult by the fact that the phase forms of bioethics continued to exist in parallel. Let us briefly summarise the development stages of bioethics with their corresponding phase definitions and key publications that articulate the features of its methodology and subject-matter in the respective periods:

1. The development stage of "new medical ethics". In its initial stage, bioethics was methodogically defined by immediate moral reflection (principlism), while its subject was restricted to healthcare and biomedical research. In the "Introduction" to the first edition of the Encyclopedia of Bioethics (1978), W. T. Reich defined bioethics in the first stage of its development as "the systematic study of human conduct in the area of the life sciences and healthcare, insofar as this conduct is examined in the light of moral values and principles" (Reich, 1995: XXVIII). A year later, T. L. Beauchamp and J. F. Childress published the influential book Principles of Biomedical Ethics (Beauchamp, Childress, 1979), which became the fundamental work of principlism.

2. The development stage of "global bioethics". In the second stage of development, bioethics was methodologically defined by means of ethical pluralism and scientific interdisciplinarity, while its scope of research expanded to the problems of life in general and to the socio-political and global-ecological context. In the second edition of the Encyclopedia 
of Bioethics (1995), W. T. Reich re-defined bioethics, noting the methodological transformation it underwent in the meantime and designating it as "the systematic study of the moral dimensions - including moral visions, decisions, conduct and policies - of the life sciences and health care, employing a variety of ethical methodologies in an interdisciplinary setting" (Reich, 1995: XXI). A decisive role in the expansion of the scope of research in bioethics on global scale was played by V. R. Potter, "the father of bioethics", who published his second book in this period, which was significantly entitled Global Bioethics: Building on the Leopold Legacy (Potter, 1988).

3. The development stage of "integrative bioethics". From the methodological point of view the current development phase of bioethics is marked by the idea of pluriperspectivity, while its scope of research is deepened by analysing its philosophico-historical dimension which sheds light on the scientific-technical character of the phase and the role of modern science. It considers the changes in the fundamental relationships of man towards historical givens and detects the processes of turns of the world-historical epochs. In the dialogue framework of bioethical co-operation which started developing in 2004 from a centre in Croatia in the region of Southeast, South and Central Europe, bioethics is defined as "a pluriperspective area in which the interplay of heterogenous perspectives establishes the footholds for orientation in the issues related to life or conditions of its sustainment" (Čović, 2005: 150-151). A large number of papers have been published within the project of "integrative bioethics", the most notable of which for our topic is the paper by Hrvoje Juric entitled "The Footholds of an Integrative Bioethics in the Work of Van Rensselaer Potter" (Jurić, 2007).

While bioethics in its first two development stages formed mainly in the United States, its most recent breakthrough in development moved to Europe, to the area of Southeast Europe where it became the centre of an intense and productive bioethical discussion.

It was in this period of the rounding off of the concept of integrative bioethics that HansMartin Sass published a serious of papers dedicated to the work of the German theologist and pastor Fritz Jahr who, in 1927, not only introduced the term bio-ethics ("Bio-Ethik") in the popular science journal Kosmos but also elaborated the original concept of that discipline (Sass, 2007), which can be considered as the predecessor of the idea of integrative bioethics because of its methodological and subject-matter aspects. This coincidence opened the horizon of European bioethics, paving the way for an appearance in full splendour of bioethical contributions in Eurocontinental philosophical thought and spiritual tradition in general, ranging from Plato and Francis of Assisi to Immanuel Kant and Albert Schweitzer.

\section{REFERENCES}

Beauchamp, T. L., Childress, J. F. (1979). Principles of Biomedical Ethics, Oxford University Press, New York. Čović, A. (2005). Bioethik unter den Bedingungen des Postkommunismus - Fallbeispiel Kroatien. In Čović, A., Hoffman, Th. S. (eds.), Bioethik und kulturelle Pluralität. Die südosteuropäische Perspektive, Academia Verlag, Sankt Augustin, 2005, pp. 148-172.

Jurić, H. (2007). Stützpunkte für eine integrative Bioethik im Werk Van Rensselaer Potters. In Čović, A., Hoffmann, Th. S. (eds.), Integrative Bioethik / Integrative Bioethics, Academia Verlag, Sankt Augustin, 2007, pp. 68-92.

Potter, V. R. (1988). Global Bioethics: Building on the Leopold Legacy, Michigan State University Press, East Lansing. 
Reich, W. Th. (1995). Introduction. In Reich W. Th. (ed.), Encyclopedia of Bioethics, Vol. I, Macmillan, New York, 1995, pp. IX-XXXII.

Sass, H.-M. (2007). Fritz Jahr's bioethischer Imperativ. 80 Jahre Bioethik in Deutschland von 1927 bis 2007 (Medizinethische Materialien des Zentrums für Medizinische Ethik, No. 175), Zentrum für Medizinische Ethik, Bochum.

\section{EVROPEIZACIJA BIOETIKE: \\ MOGUĆNOSTI INTEGRATIVNE ETIČKE REFLEKSIJE NA TEMELJU INTRAKULTURNIH RAZLIKA U EVROPI}

Članak predstavlja rekonstrukciju teorijskog okvira u kojem je razvijen koncept integrativne bioetike, kao i verifikovanje ideje evropeizacije bioetike koja je skicirana i postulirana na počecima obimnog internacionalnog projekta zasnivanja i institucionalizovanja bioetičke saradnje, prvenstveno u regiji jugoistočne Evrope. Ova ideja je čvrsto utemeljena na konceptu integrativne bioetike i u otkriću dela Frica Jara, koje je doprinelo utemeljenju koncepta evropske bioetike. Kompoziciono gledano, ovaj članak je rezultat sinteze programatskih ideja koje su prezentovane u inicijalnoj fazi gore pomenutog bioetičkog projekta i ideja koje predstavljaju njegovu završnu tačku.

Ključne reči: bioetika, nova medicinska etika, globalna bioetika, integrativna bioetika, evropska bioetika, Fric Jar 